\title{
S 7
}

UNDERSTANDING TOWARDS MEDICAL GENETICS AND THE ROLE OF PHYSICIANS AND MASS MEDIA. Kunihiko KUMAMOTO (Div. Science News, NHK, Tokyo)

We at NHK have broadcast of Jan. 17, 1992 a program called "Can you select your child's 1ife?" on PRIME 10. The program looks at the present prenatal testing today and the advanced technolgy as well as interviewing those couples who have had their fetus be diagnosed where it has brought about major discussion and debate both domestically and abroad. At the same time, we compare two cases one in the U.S. a Chicago couple who can go to a genetic counsellor easily to discuss about genetics and their child, and a case in Japan's Shizuoka Prefecture where a couple knowing that the wife is a hemophiliac but nevertheless was not able to get information on prenatal testing beforehand. Major hospitals in the U.S. have outpatients for the clinical genetics branch, and there are approximately 1000 genetic counsellors in the U.S. Whilst in the U.S. such medical genetics advancement is being utilized in the clinical field, Japan is quite behind. So, I feel that we the mass media people (through correct information transmission) together with those physicians and researchers of medical genetics (making systems where medical information could be carried forward) should work together to come up with a better way to handle things.

\section{Symposium II.}

\section{S 8}

CHROMOSOME TRANSLOCATIONS AND MOLECULAR MECHANISM IN LEUKEMIA. Yasuhiko KANEKO

(Dept. Lab. Med., Saitama Cancer Center, Saitama)

Various translocations are found in half of leukemias. There have been 61 translocations specific for certain types of leukemias reported previously (Human Gene Mapping 11). 37 genes have been cloned from the breakpoint regions and characterized. The translocations found in lymphocytic leukemia usually involve immunoglobulin genes or $T-c e l l$ receptor genes and result in transcriptional deregulation of the counterpart oncogenes. Those in myelocytic leukemia result in the production of chimeric mRNA and protein. Transcriptionally deregulated oncogenes or chimeric proteins transform normal hematopoietic cells to leukemic cells.

We have cloned the AML1 and MTG8 genes from the $21 \mathrm{q} 22$ and $8 \mathrm{q} 22$ regions, respectively, of the $8: 21$ translocation associated with acute myeloblastic leukemia (M2). The chimeric protein has DNA binding domains and seems to deregulate the transcription of an unknown target gene. The RT-PCR method to detect minimal amount of the chimeric AML1-MTG8 mRNA may be useful for monitoring small numbers of leukemic cells during the course of the disease. 


\title{
S 9
}

\author{
DETECTION OF DNA ABERRATIONS IN HUMAN CANCERS BY SINGLE- \\ STRAND CONFORMATION POLYMORPHISM ANALYSIS OF POLYMERASE \\ CHAIN REACTION PRODUCTS. Takao Sekiya (Oncogene Division, National \\ Cancer Center Research Institute, Tokyo)
}

For detecting single-base substitutions at unknown positions of target DNA fragments, we developed a method named single-strand conformation polymorphism (SSCP) analysis (1). Single-stranded DNA fragments carrying the same nucleotide sequence but with a single-base substitution form different conformations and the difference can be detected by mobility shift on non-denaturing polyacrylamide gel electrophoresis. SSCP analysis of a DNA fragment amplified and labeled by the polymerase chain reaction provides a simple, sensitive method (PCR-SSCP) for detection of point mutations (2). Our results indicated the efficiency of detection of single-base substitutions in fragments of less than 300 base pairs was more than $90 \%$ when both strands were labeled. We have successfully used PCR-SSCP analysis for detection of mutated oncogenes and tumor suppressor genes in human cancers including lung cancers $(3,4)$, hepatocellular carcinomas (5), pancreatic cancers and others. Our results indicated the efficiency of detection of single-base substitutions in fragments of less than 300 base pairs was more than $90 \%$ when both strands were labeled.

(1) M. Orita, H. Iwahana, H. Kanazawa, K. Hayashi and T. Sekiya, Proc. Natl. Acad. Sci. USA, 86, 2766 (1989). (2) M. Orita, Y. Suzuki, T. Sekiya and K. Hayashi, Genomics, 5, 874 (1989). (3) Y.

Suzuki, M. Orita, M. Shiraishi, K. Hayashi and T. Sekiya, Oncogene, 5, 1037 (1990). (4) Y. Kishimoto, Y. Murakami, M. Shiraishi, K. Hayashi and T. Sekiya, Cancer Res. 52, 4799 (1992). (5) Y. Murakami, K. Hayashi,.S. Hìrohashi and T. Sekiya, Cancer Res., 51, 5520 (1991).

Multi-step carcinogenesis of colorectal cancer. Yusuke Nakamura (Dept. Biochem., Cancer Institute, Tokyo)

Transformation of a normal cell to a malignant cell is caused by an accumulation of genetic alterations in oncogenes and tumor suppressor genes. In colorectal tumor, five genes associated with development and/or progression of adenomas and carcinomas were discovered and the role of each gene during carcinogenesis has been suggested. The APC (adenomatous polyposis coli) gene, which is isolated as a responsible gene for familial adenomatous polyposis (FAP), is frequently mutated in sporadic form of colorectal tumors and is considered to be important for an adenoma formation. A point mutation of the $\mathrm{K}$-ras oncogene is associated at the second step and its mutation makes the size of adenoma large. A somatic mutation of the p53 gene or MCC (mutated in colorectal carcinoma) gene in addition to the mutations in the APC and K-ras genes, transforms a benign tumor cell to a malignant tumor cell. Inactivation of the DCC gene might be associated with progression of tumors and increase a chance to cause metastasis to other organs. 